\title{
Pembangunan Akses Air Bersih Pasca Krisis Covid-19
}

\author{
Eko Wiji Purwanto ${ }^{1}$ \\ Kementerian Perencanaan Pembangunan Nasional/Bappenas Republik Indonesia
}

\begin{abstract}
Abstraksi
Penyediaan akses air bersih/air minum adalah urusan pemerintahan yang konkuren dan bersifat wajib. Pemenuhan air bersih dilakukan dengan pendekatan yang berbasis masyarakat atau mandiri, dan berbasis lembaga melalui badan usaha milik daerah (BUMD) di bidang air minum. Adanya wabah Covid-19 telah mempengaruhi segala sektor kehidupan masyarakat. Namun, secara spesifik dampak Covid-19 di sektor air bersih nasional belum nyata terlihat. Sehingga belum nyata pengaruhnya terhadap upaya pemenuhan akses universal air minum aman tahun 2030, sebagai tujuan pembangunan berkelanjutan (TPB) akses air minum. Adanya krisis ini justru menjadi peluang untuk lebih mengedepankan air bersih sebagai sektor yang perlu menjadi prioritas karena perannya sebagai garda terdepan dalam mencegah penyebaran Covid-19. Krisis Covid-19 diharapkan dapat mendorong peningkatan anggaran di sektor ini sekaligus penataan kembali kelembagaan sektor air bersih. Banyaknya pemangku kepentingan di sektor air bersih membutuhkan adanya leadership yang mumpuni, juga perlu adanya otoritas yang menjadi leading institution di sektor air bersih.
\end{abstract}

Kata kunci: akses air bersih; covid-19; Indonesia; krisis;

\footnotetext{
1 Eko Wiji Purwanto adalah Perencana Madya di Kementerian PPN/Bappenas. E-mail: ekow.purwanto@bappenas.go.id
} 


\title{
Pembangunan Akses Air Bersih Pasca Krisis Covid-19
}

\author{
Eko Wiji Purwanto
}

\section{Pendahuluan}

Cita-cita kemerdekaan yang dituliskan dalam Pembukaan UUD 1945 alinea ke empat antara lain adalah mewujudkan kesejahteraan umum dan mencerdaskan kehidupan bangsa. Ketersediaan air bersih yang berkelanjutan adalah bagian dari upaya mewujudkan tercapainya cita-cita tersebut. Akses air bersih yang memadai akan meningkatkan derajat kesehatan masyarakat. Masyarakat yang sehat dan produktif menjadi modal dasar untuk mewujudkan Indonesia yang adil, makmur, dan sejahtera.

Pemerintah berkewajiban untuk menyediakan layanan air bersih untuk sebesarbesarnya kesejahteraan masyarakat2. Undang-Undang 23/2014 tentang Pemerintahan Daerah menyatakan bahwa urusan pemerintahan yang terkait pelayanan dasar merupakan urusan pemerintahan yang konkuren dan bersifat wajib. Penyediaan akses air bersih/ air minum 3 adalah urusan pemerintahan yang konkuren dan bersifat wajib; urusan pemerintahan yang penyelenggaraannya dibagi antara Pemerintah Pusat, Provinsi dan Kabupaten/Kota.

\section{Permasalahan}

Pemerintah terus berupaya meningkatkan cakupan akses air minum di Indonesia melalui beragam pendekatan. Secara umum ada dua pendekatan utama yang dilakukan, yaitu pendekatan berbasis masyarakat dan pendekatan berbasis lembaga.

Pendekatan berbasis masyarakat mendorong masyarakat berperan aktif sebagai pelaku utama penyediaan akses air bersih dari hulu hingga ke hilir, dari mulai pengambilan air baku hingga distribusinya ke rumah tangga. Pendekatan ini utamanya diimplementasikan di kawasan perdesaan yang masih sulit dijangkau oleh perusahaan daerah air minum (PDAM).

Pendekatan yang kedua adalah pendekatan berbasis lembaga. Penyediaan akses layanan air bersih melalui badan usaha milik daerah (BUMD) di bidang air minum. Pemda membentuk BUMD air minum sebagai pelaku utama dalam penyediaan akses air minum. BUMD ini dapat berbentuk perumda ataupun perusda air minum 4 yang operasionalnya masih terbatas di ibukota kabupaten/ kota atau kawasan perkotaan saja.

Agenda SDGs mengamanatkan Pemerintah Indonesia untuk mewujudkan akses universal air minum aman pada tahun 2030. Penyediaan air minum yang berbasis masyarakat dan berbasis lembaga hingga saat ini baru dapat menyediakan air bersih dengan kualitas terbatas. Apakah kondisi krisis yang disebabkan oleh Pandemi Covid-19 dapat

\footnotetext{
${ }^{2}$ Bumi, air dan kekayaan alam yang terkandung didalamnya dikuasai oleh Negara dan dipergunakan untuk sebesarbesarnya kemakmuran rakyat (Pasal 33 ayat 3 , UUD 45).

${ }^{3}$ Permenkes No. 492/Menkes/PER/IV/2010 tentang Persyaratan Kualitas Air Minum menyatakan bahwa air minum adalah air yang melalui proses pengolahan atau tanpa proses pengolahan yang memenuhi syarat kesehatan dan dapat langsung diminum. Sementara Kepmenkes No. 1405/Menkes/SK/IX/2002 tentang Persyaratan Kesehatan Lingkungan Kerja Perkantoran dan Industri menyebutkan bahwa air bersih adalah air yang dipergunakan untuk keperluan sehari-hari dan kualitasnya memenuhi persyaratan kesehatan air bersih sesuai dengan peraturan perundangundangan yang berlaku dan dapat di minum apabila dimasak. Batasan mengenai air bersih dan air minum ini dapat dipertukarkan jika menggunakan referensi tersebut di atas.

${ }^{4}$ BUMD ini lebih dikenal dengan nama PDAM (Perusahaan Daerah Air Minum). Seiring pemberlakuan Peraturan Pemerintah nomor 54 tahun 2017 tentang Badan Usaha Milik Daerah, BUMD air minum dapat berbentuk perusahaan umum daerah (perumda) atau perusahaan perseroan daerah (perseroda).
} 
mempengaruhi upaya pemenuhan akses universal air minum aman tahun 2030? Bagaimana mengupayakan percepatan peningkatan akses di tengah dampak krisis akibat Covid-19?

\section{Pembahasan}

Rencana Pembangunan Jangka Menengah Nasional (RPJMN) 2020-204 menuliskan bahwa pembangunan infrastruktur adalah salah satu pilihan strategis dalam rangka percepatan pertumbuhan dan pemerataan ekonomi nasional. Fokus pembangunan infrastruktur untuk periode 2020-2024 adalah infrastruktur yang mendukung pemerataan pelayanan dasar, pembangunan ekonomi, dan perkotaan.

RPJMN 2020-2024 juga mencatat pencapaian kinerja akses pelayanan air bersih yang masih belum cukup memuaskan pada periode pembangunan sebelumnya. Peningkatan akses air minum layak dan aman masih perlu terus dioptimalkan. Ada beragam tantangan dalam penyediaan akses air minum; mulai dari masih lemahnya tata kelola dan kelembagaan, hingga masih terbatasnya komitmen dan kapasitas pemerintah daerah. Sampai tahun 2018, akses air minum layak di Indonesia sudah mencapai $87,75 \%$ dari populasi, namun yang menikmati akses perpipaan baru sekitar 20,14\%.

Sustainable Development Goals (SDGs) 2030 mencanangkan tujuan pembangunan berkelanjutan (TPB) akses air minum adalah akses universal untuk seluruh masyarakat dengan air minum yang harus memenuhi kriteria sebagai air minum aman; dari sumber air yang layak, berada di dalam atau di halaman rumah, dapat diakses setiap saat dibutuhkan, dan kualitasnya memenuhi standar kesehatan. Sejauh ini akses air minum aman di Indonesia diperkirakan baru sekitar 6,8\% rumah tangga.

Target TPB air minum di 2030 cukup berat: akses air minum aman untuk seluruh masyarakat. Dalam RPJMN 2020-2024 yang merupakan bagian terakhir dari Rencana Pembangunan Jangka Panjang Nasional (RPJPN) 2005-2025 telah di identifikasi permasalahan yang ada dalam percepatan akses air minum nasional. Tantangan terkini yang harus dihadapi adalah adanya pandemi Covid-19.

Covid-19 menjadi momok yang menghantui berbagai bangsa, tidak terkecuali bangsa Indonesia. Covid-19 mempengaruhi secara signifikan hampir seluruh perikehidupan. Perekonomian bangsa-bangsa menjadi lebih rapuh. Beragam sektor terdampak. Sedikit sektor yang dapat survive dalam pandemi Covid-19. Sektor terkait kesehatan termasuk yang mendapatkan tantangan dan peluang secara sekaligus. Sektor air bersih yang erat kaitannya dengan kesehatan masyarakat termasuk yang mendapatkan tantangan dan peluang sekaligus.

\subsection{Dampak Covid-19 di Sektor Air Bersih}

Secara umum pandemi Covid-19 memberikan dampak negatif bagi perekonomian. Dampak krisis akibat Covid-19 terlihat nyata pada sektor-sektor utama perekonomian seperti pariwisata, transportasi, dan produksi barang-jasa lainnya. Kemerosotan tersebut langsung terefleksikan dalam data-data perekonomian. Dampak Covid-19 terhadap sektor air bersih yang merupakan kebutuhan infrastruktur dasar sejauh ini belum nyata terlihat.

Kondisi potensial yang mungkin terjadi pada sektor air bersih saat krisis ini adalah turunnya pendapatan pada badan usaha/lembaga pengelola sistem penyediaan air bersih akibat menurunnya permintaan dari sektor non-rumah tangga (industri dan komersial) dan meningkatnya konsumsi di sektor rumah tangga dengan peningkatan penerimaan pendapatan yang tidak sepadan dengan hilangnya penerimaan dari sektor non-rumah 
tangga. Sejauh ini belum ada data makro yang cukup lengkap untuk memotret dampak krisis Covid-19 pada industri air bersih nasional yang masih merupakan domain BUMD.

Penurunan permintaan air bersih dari sektor non-rumah tangga adalah dampak turunan dari melemahnya perekonomian nasional. Berbagai industri dan usaha komersial mengurangi jumlah produksi, mengurangi jumlah jam kerja, bahkan mengurangi jumlah tenaga kerja. Kurva permintaan air bersih dari sektor ini baru akan pulih seiring pulihnya perekonomian.

Pada kelompok rumah tangga, konsumsi air bersih berpotensi mengalami peningkatan karena adanya kebijakan bekerja, bersekolah, dan beribadah di rumah. Namun kenaikan ini tidak dapat mengompensasi hilangnya penerimaan karena turunnya permintaan sektor non-rumah tangga akibat tingginya disparitas harga antar kelompok pelanggan .

Alih-alih mengeluhkan kinerja pendapatan karena merosotnya permintaan akibat krisis, BUMD air minum bahkan berinisiatif memberikan pembebasan tarif layanan bagi kelompok masyarakat tertentu . Pembebasan tarif ini tentunya atas persetujuan atau bahkan merupakan mandat dari Kepala Daerah sebagai pemilik PDAM. Perlu ditelisik lebih jauh dampaknya bagi keuangan badan usaha dalam jangka menengah .

Sebagai infrastruktur layanan dasar yang wajib disediakan pemerintah, dampak krisis diduga akan mengurangi ketersediaan anggaran sektor karena adanya kebijakan refokusing anggaran di saat krisis. Pada pendekatan penyediaan air minum berbasis masyarakat pengurangan anggaran ini berpotensi memperlambat percepatan penyediaan akses air minum di daerah yang belum dilayani PDAM, sementara pada pendekatan berbasis lembaga akan mengurangi dukungan pemerintah terhadap percepatan perluasan akses layanan air minum PDAM.

Dalam perspektif lainnya, situasi krisis yang disebabkan oleh Covid-19 menyadarkan perlunya aspek perilaku hidup bersih dan sehat (PHBS) untuk meminimalkan potensi penyebarluasan Covid-19. Ketersediaan air bersih yang memadai menjadi prasyarat terwujudnya PHBS. Covid-19 dapat menjadi pintu masuk untuk mengadvokasi dan mengubah mindset para pemangku kepentingan kunci tentang pentingnya air bersih.

Pemerintah Afrika Selatan menjadi contoh munculnya kesadaran pemangku kepentingan kunci tentang pentingnya air bersih (untuk mencuci tangan) dalam upaya mencegah penyebaran Covid-19. 41 ribu titik penyediaan air bersih tambahan dibangun Pemerintah Afrika Selatan di seluruh pelosok negeri agar seluruh masyarakat mendapatkan akses air bersih untuk cuci tangan. Sementara sebelumnya pemerintah relatif kurang memprioritaskan akses air bersih (Cristopher Gasson, 2020).

Covid-19 memaksa Pemerintah Afrika Selatan melakukan langkah dramatis karena Covid-19 tidak peduli kelas dalam masyarakat, dapat menyerang kelompok masyarakat miskin maupun kelompok masyarakat kaya. Jika keterbatasan akses air bersih untuk kelompok masyarakat terbawah hanya akan menyebabkan kelompok ini yang mendapatkan waterborne disease, maka Covid-19 membunuh yang kaya dan miskin, tanpa membedakan kelas dalam masyarakat, sekaligus merontokkan perekonomian. Kelompok masyarakat kaya, hanya akan survive jika kelompok masyarakat miskin juga survive.

Dalam perspektif sektor air bersih, ini adalah krisis yang dapat mendorong pemerintah menyadari pentingnya air bersih menjadi prioritas. Kebutuhan akan air bersih untuk melakukan PHBS ini seyogyanya membuka kesadaran baru bahwa ketersediaan air bersih adalah garda terdepan dalam menjaga dan meningkatkan derajat kesehatan masyarakat. Pengampu sektor air bersih harus dapat menggunakan momen krisis ini untuk 
lebih mendapatkan dukungan pemangku kepentingan kunci lainnya dalam melakukan perluasan layanan. Untuk mengejar target SDGs 2030 berbagai tantangan dan peluang yang dapat mempengaruhi kinerja sektor perlu di antisipasi.

\subsection{Pendanaan}

Air bersih adalah kebutuhan dasar. Perlu disiapkan anggaran pembangunan yang mencukupi untuk mendorong terwujudnya akses air minum aman di tahun 2030. Sejauh ini anggaran pemerintah dalam 5 tahun terakhir untuk sektor air bersih berkisar Rp. 3,5-6,5 triliun dengan rerata per tahun sebesar Rp. 4,5 triliun . Jika Jumlah ini dapat dipertahankan setiap tahunnya, hingga 2030 akan tersedia dana pemerintah sekitar Rp. 45 triliun. Masih sangat jauh dari kebutuhan pembangunan hingga tahun 2024 yang sebesar Rp. 147 triliun atau bahkan kebutuhan pendanaan tahun 2030 sebesar Rp. 238 triliun (Bappenas, 2019) .

Ketersediaan anggaran untuk pembangunan sektor air bersih masih jauh dari kebutuhannya, bahkan di saat sebelum pandemi Covid-19. Refocusing anggaran yang dilakukan saat krisis diharapkan tidak menggerus dana yang sudah sangat terbatas. Merujuk kembali pada pasal 33 ayat 3 UUD 1945, idealnya anggaran pemerintah untuk pembangunan sektor air bersih ditingkatkan secara masif, mendekati kebutuhan riil yang ada di masyarakat.

Sampai tahun 2018, akses air minum layak di Indonesia sudah mencapai 87,75\%. Namun, hanya 6,8\% penduduk yang sudah menikmati akses aman. Masih ada gap 80,95\% penduduk di tahun 2018 yang masih perlu ditingkatkan aksesnya dari akses layak menjadi akses aman.

Secara keseluruhan sebanyak 93,2\% penduduk belum mendapatkan akses aman. Jika angka tersebut di terjemahkan dalam kebutuhan pendanaan, estimasi besaran angkanya hingga tahun 2030 dapat lebih besar Rp. 238 triliun jika tingkat inflasi diperhitungkan. Besaran kebutuhan pendanaan tersebut diharapkan 30\%nya dapat dialokasikan oleh pemerintah daerah (Bappenas, 2019).

Tantangan untuk dapat memenuhi besaran pendanaan tersebut jelas tidak mudah. Jika APBN masih belum mampu menyediakan besaran kebutuhan untuk anggaran pembangunan sektor, maka kemungkinan pemerintah daerah untuk dapat mengalokasikan APBD seperti yang diharapkan oleh pemerintah pusat pun nyaris mustahil. Data lapangan yang pernah dikumpulkan oleh Kelompok Kerja Air Minum dan Penyehatan Lingkungan mengindikasikan rerata besaran APBD untuk sektor air minum dan sanitasi hanya sekitar $2 \%$ per tahunnya.

Pemenuhan kebutuhan anggaran pembangunan sektor air minum sejauh ini masih menjadi pekerjaan rumah besar bagi para pengampu sektor. Pembangunan sektor cukup terbantu dengan adanya sumber-sumber pendanaan non-pemerintah melalui program dan kegiatan dari donor, NGO, dan kelompok masyarakat madani lainnya.

Potensi lainnya adalah pendanaan dalam bentuk kerjasama pemerintah dan badan usaha, yang sejauh ini masih belum dieksplorasi dengan optimal. Program dan kegiatan yang bersumber dari tanggung-jawab sosial perusahaan juga berpotensi untuk dimanfaatkan secara lebih optimal. Ada gap pendanaan yang sangat signifikan dalam pembangunan infrastruktur dasar air bersih sebelum krisis dan mungkin akan semakin besar gap tersebut pasca Covid-19. 


\subsection{Kelembagaan}

SDGs mengamanatkan akses air minum aman. Pembangunan sektor air bersih yang selama ini mengadopsi pendekatan berbasis masyarakat dan berbasis lembaga perlu ditinjau ulang. Untuk mewujudkan akses air minum aman kedua pendekatan tersebut harus dilengkapi dengan upaya untuk meningkatkan kualitas air yang dihasilkan, memenuhi kriteria aman yang dipersyaratkan SDGs.

Dalam pendekatan berbasis masyarakat, implementasi Rencana Pengamanan Air minum (RPAM) adalah sebuah keharusan. RPAM adalah upaya pencegahan, perlindungan, serta pengendalian pasokan air minum aman bagi masyarakat Indonesia.

Konsep RPAM pada prinsipnya adalah manajemen risiko dari sumber air hingga ke masyarakat (konsumen). Implementasi konsep ini diharapkan dapat meningkatkan akses pelayanan air bersih yang memenuhi kaidah $4 \mathrm{~K}$ : Kualitas, Kuantitas, Kontinuitas, dan Keterjangkauan. Uji coba RPAM sudah dilakukan sejak tahun 2014, namun hasilnya masih belum optimal.

Pada pendekatan berbasis kelembagaan melalui PDAM, inisiatif pengembangan Zona Air Minum Prima (ZAMP) perlu diperluas secara sungguh-sungguh. Belum semua PDAM dapat menyediakan akses air minum aman. Inisiatif yang saat ini dilakukan adalah dengan pengembangan ZAMP dalam skala terbatas. Salah satu kendala terbesarnya adalah kesiapan sarana dan prasarana di PDAM, termasuk kesiapan sumberdaya manusia PDAM dan kapasitas pemda jika ingin mengimplementasikan zona air minum prima dalam skala yang masif.

RPAM dan ZAMP adalah inisiatif yang sudah diluncurkan oleh pengampu sektor air minum untuk menuju terwujudnya akses air minum aman. Pada prinsipnya kedua inisiatif ini mengedepankan pendekatan manajemen risiko yang terintegrasi dari hulu ke hilir; dari sumber air, proses pengolahan dan distribusinya, hingga ke tangan konsumen/ masyarakat. RPAM dan ZAMP adalah upaya untuk menjaga keamanan kualitas air yang dikonsumsi oleh masyarakat.

Kedua inisiatif ini menghadapi tantangan dalam implementasinya. Beragamnya pemangku kepentingan yang terlibat, lintas sektor dan lintas pemerintahan, menyebabkan hasil dari upaya tersebut belum optimal. Sumber air yang ada, khususnya air permukaan, seringkali melintasi batas administratif kabupaten/kota/provinsi. Perbedaan kebijakan di setiap tingkatan pemerintahan dan pembagian kewenangan antar kementerian/ lembaga dari hulu hingga ke hilir juga menjadi kendala tersendiri.

Pembagian urusan pusat dan daerah di sektor air minum belum berlangsung seperti yang diharapkan. Penafsiran UU 23/2014 yang mengamanatkan air minum sebagai urusan konkuren yang diselenggarakan bersama oleh seluruh tingkatan pemerintahan justru berkecenderungan menyebabkan masing-masing tingkat pemerintahan tergantung kepada yang lain.

Tantangan utama dalam upaya mewujudkan akses universal air minum aman selain persoalan pendanaan adalah penataan kelembagaan di sektor air minum. Proses penyediaan akses air minum dari hulu ke hilir, dari mulai pengambilan air baku hingga proses distribusi layanan melibatkan banyak institusi. Penataan kembali kelembagaan terkait sektor air minum perlu diupayakan dengan sungguh-sungguh. Terlalu banyaknya pihak yang terlibat dalam sektor air minum, tidak diimbangi dengan adanya leadership yang kuat dalam pengelolaan sektor. 


\subsection{Strategi ke Depan}

Mewujudkan TPB 2030 untuk akses air minum aman mempersyaratkan penambahan jumlah akses air bersih di masyarakat secara kuantitas dan kualitas. Pendekatan berbasis masyarakat dan berbasis lembaga yang selama ini dilakukan dalam penyediaan akses air bersih perlu dimodifikasi. Penambahan akses secara kuantitas dan kualitas secara spesifik wajib mengintegrasikan manajemen risiko dari hulu ke hilir; dari sumber air hingga ke rumah tangga.

Implementasi RPAM untuk pendekatan berbasis masyarakat dan ZAMP untuk pendekatan berbasis lembaga perlu diperluas dan ditingkatkan kualitasnya. Peran pemda sebagai ujung tombak pelayanan publik perlu dibenahi. Covid-19 membuktikan pentingnya peranan air bersih sebagai garda terdepan dalam pencegahan penyebaran penyakit. Ketersediaan akses air bersih yang aman akan mendorong peningkatan derajat kesehatan dalam jangka panjang.

Kompleksitas pengelolaan sektor air bersih membutuhkan penataan kelembagaan yang dapat mengakselarasi percepatan penambahan akses air bersih secara kuantitas dan kualitas. Perlu disiapkan otoritas yang memiliki kewenangan dari hulu ke hilir terkait sektor air minum.

Otoritas tersebut menjadi leading institutions dalam penyediaan akses air minum yang merupakan urusan pemerintahan konkuren. Pemangku kepentingan lainnya yang terlibat mengikuti arahan dari otoritas nasional yang memiliki kewenangan dan kapasitas pengaturan, pengawasan, dan pengendalian kinerja penyediaan air minum dari hulu hingga hilir. Otoritas dengan kewenangan dari hulu ke hilir tersebut menyelesaikan berbagai persoalan yang melingkupi sektor air minum; meninjau kembali kerangka regulasi, kerangka investasi, dan kerangka pendanaan terkait dengan penyediaan air bersih untuk air minum.

Dalam melaksanakan tugasnya otoritas memperhatikan keunikan sistem penyediaan air minum dimana air yang mengalir dari hulu ke hilir dapat bersifat lintas kabupaten/kota bahkan provinsi. Kerangka regulasi terkait air minum disederhanakan. Birokrasi proses penyediaan air minum mengutamakan pencapaian outcome utama: peningkatan layanan akses air bersih untuk air minum, bukan lagi soal kepemilikan PDAM, kepemilikan sumber air, ataupun hal lain yang bersifat input-output semata.

Secara mikro peningkatan akses air minum aman dapat dimulai dari pelaksanaan tata kelola dan manajemen risiko yang optimal melalui implementasi RPAM dan ZAMP. Secara makro penetapan leading institution air minum secara nasional, yang memiliki kewenangan dari hulu ke hilir dalam pembangunan sektor air minum, dapat menjadi mitra pemda untuk lebih sungguh-sungguh meningkatkan akses air minum aman. Pemerintah perlu menginventarisasi kelembagaan di pusat yang dapat berperan sebagai otoritas sektor air minum yang berperan sebagai leading institution, menjadi otoritas pengatur sistem penyediaan air minum secara nasional.

Jika persoalan kelembagaan sudah mulai teruraikan maka persoalan pendanaan diharapkan dapat lebih mudah diupayakan. Ada ragam sumber pendanaan yang bisa diupayakan di luar sumber-sumber pemerintah. Persoalannya, kurang solidnya kelembagaan dalam pengelolaan sektor air bersih mengakibatkan optimasi sumber-sumber non pemerintah belum dilaksanakan dengan baik. Kerjasama pemerintah dengan badan usaha, badan usaha dengan badan usaha, pembiayaan campuran (blended financing), dan tanggung jawab sosial perusahaan (CSR) mensyaratkan adanya transparansi dan akuntabilitas dalam tatakelolanya. Adanya leading institution dengan leadership yang kuat dalam pengelolaan 
sektor akan memudahkan para mitra pembangunan bekerjasama dalam mendukung pembangunan sektor air minum di masa depan.

\section{Kesimpulan dan Rekomendasi}

Data dan ulasan yang disampaikan di bagian sebelumnya mencoba mengilustrasikan bahwa secara spesifik dampak Covid-19 di sektor air bersih nasional belum nyata terlihat. Hipotesis akibat pandemi Covid-19 terhadap sektor air bersih mengindikasikan potensial setback untuk sektor air bersih. Namun krisis ini juga menjadi peluang untuk lebih mengedepankan air bersih sebagai sektor yang perlu menjadi prioritas karena perannya sebagai garda terdepan dalam mencegah penyebaran Covid-19.

Potensi pendanaan air bersih masih jauh dari kebutuhan yang diharapkan. Krisis Covid-19 diharapkan dapat mendorong peningkatan anggaran di sektor ini. Selain peningkatan pendanaan, penataan kembali kelembagaan sektor air bersih layak dipertimbangkan. Banyaknya pemangku kepentingan di sektor air bersih membutuhkan adanya leadership yang mumpuni. Perlu ada otoritas yang menjadi leading institution di sektor air bersih.

\section{Daftar Pustaka}

Bappenas, Bahan Rapat Program 10 Juta Sambungan Air Minum, Rakor Kantor Wakil Presiden, 8 April 2019.

Bappenas, Perhitungan Baseline dan Target RPJMN 2020-2024 Bidang Air Minum, Bahan Paparan Direktorat Perkotaan, Perumahan, dan Permukiman, 17 Februari 2020.

Budi Sutjahyo, Pengantar Peningkatan Kualitas Air Minum, Bahan Paparan BPPSPAM, Malang, Oktober 2008.

Cristopher Gasson, Using the COVID-19 Crisis for A Better Water Sector, article published on https://www.globalwaterintel.com/news/2020/14/using-the-covid-19-crisis-for-abetterwater-sector, diakses 9 Mei 2020.

Direktorat Keterpaduan Infrastruktur Permukiman, Data Realisasi Anggaran TA 20152019 dan Rencana Pemotongan Anggaran APBN TA 2020, Jakarta, 2020.

Eko Wiji Purwanto, Kelayakan PDAM sebagai Badan Usaha Milik Daerah: Kertas Kebijakan, Pelatihan Fungsional Penjenjangan Perencana Utama - Angkatan XI LPEM-FEB Universitas Indonesia, Jakarta, Agustus 2019.

Eko Wiji Purwanto, Catatan Diskusi dan Wawancara dengan Pemangku Kepentingan PDAM, Jakarta, Mei 2020.

Farid Baknur, Kondisi BUMD Air Minum Pasca Pandemi Covid-19, Draft Bahan Paparan BPPSPAM, April 2020.

Isharyanto, Pokok-Pokok Pikiran Pengaturan BUMD, Paparan Seminar Rancangan Peraturan Daerah tentang Penyelenggaraan BUMD di DPRD Provinsi Jawa Tengah, Semarang, 31 Juli 2018

Republik Indonesia, Undang Undang Dasar 1945.

Republik Indonesia, Undang Undang Nomor 23 Tahun 2014 tentang Otonomi Daerah.

Republik Indonesia, Peraturan Pemerintah Nomor 54 Tahun 2017 tentang Badan Usaha Milik Daerah.

Republik Indonesia, Peraturan Presiden Nomor 18 Tahun 2020 tentang Rencana Pembangunan Jangka Menengah Nasional Tahun 2020-2024

https://www.google.com/search?q=pdam+corona\&rlz=1C1CHBF_enID835ID835\&oq=p dam \&aqs=chrome.0.69i59j69i57jol6.3209joj8\&sourceid $=$ chrome\&ie $=U T F-8$, diakses 8 Mei 2020.

http://www.ampl.or.id/program/Rencana-Pengamanan-Air-Minum-(RPAM)-/24, diakses tanggal 12 Mei 2020 